\title{
PERAN WALHI SUMBAR DALAM INVESTIGASI TAMBANG EMAS ILEGAL DI KOTA PADANG
}

\author{
Rima Fajri Yani ${ }^{1}$, Asrinaldi ${ }^{2}$, Didi Rahmadi ${ }^{3}$ \\ ${ }^{1}$ Jurusan Ilmu Politik, Fisip, Universitas Andalas, rimafajriyani70@gmail.com \\ ${ }^{2}$ Jurusan Ilmu Politik, Fisip, Universitas Andalas \\ ${ }^{3}$ Jurusan Ilmu Politik, Fisip, Universitas Andalas
}

\begin{abstract}
Abstrak
Pengelolaan sumber daya alam tidak terlepas dari permasalahan perizinan aktivitas pertambangan ilegal, salah satu kasus yang terjadi pada awal tahun 2018 adalah adanya investigasi WALHI Sumatera Barat bersama forum organisasi masyarakat setempat dalam melakukan penyelidikan terhadap aktivitas tambang emas illegal di Bukik Bulek Kelurahan Lambung Bukit Kecamatan Pauh Kota Padang. Peneliti melihat adanya peran LSM sebagai aktor tidak langsung yang mempunyai peran penting dalam tata kelola pengelolaan sumber daya alam yang demokratis dan transparan, dan peran tersebut peneliti lihat dari langkah-langkah yang dilakukan oleh WALHI Sumatera Barat dalam melakukan investigasi kasus tambang emas illegal di kawasan Bukik Bulek Kota Padang. Adapun tujuan dari penelitian ini adalah untuk menggambarkan bagaimana peran WALHI Sumatera Barat sebagai aktor tidak langsung dalam penyelidikan tambang emas illegal di kawasan Bukik Bulek Kota Padang. Penelitian ini menggunakan metode kualitatif dengan pendekatan studi kasus. Hasil penelitian ini, menunjukkan bahwa WALHI sebagai aktor tidak langsung dalam arena politik lingkungan hanya memainkan 2 peran yaitu, Countervailing Power (Kekuatan Penyeimbang) dengan dengan menggunakan langkah lobby,pernyataan sikap dan aksi massa, dan Empowerment (Pemberdayaan) dengan menggunakan langkah pengorganisasian masyarakat, dialog antar tokoh dan public campaign adapun peran lain yang dilakukan oleh WALHI Sumbar adalah membangun kerja sama dengan forum organinsasi masyarakat setempat dalam proses memframing isu investigasi temuan tambang emas ilegal yang dilakukan.

Kata Kunci:Peran LSM; Politik Lingkungan; Tambang Ilegal
\end{abstract}

\begin{abstract}
Natural resource management is inseparable from the problem of licensing illegal mining activities, one of the cases that occurred in early 2018 was the investigation of WALHI West Sumatra together with a community organization forum in conducting an investigation of illegal gold mining activities in Bukik Bulek, Lambung Bukit Village, Pauh District, Padang City. Researchers see the role of NGOs as indirect actors who have an important role in the management of natural resources management that is democratic and transparent, and that role is seen by the steps taken by WALHI West Sumatra in investigating cases of illegal gold mining in the Bukik area Bulek Kota Padang. The purpose of this study is to describe how the role of WALHI West Sumatra as an indirect actor in the investigation of illegal gold mines in the Bukik Bulek area of Padang City. This research uses a qualitative method with a case study approach. The results of this study, show that WALHI as an indirect actor in the political arena of the environment only plays 2 roles namely, Countervailing Power by using lobbying steps, statements of attitude and mass action, and Empowerment (Empowerment) using community organizing steps, dialogue between figures and public campaigns. As for the other role carried out by WALHI Sumbar, is to build cooperation with local community organization forums in the process of framing the issue of investigating illegal gold mining findings.

Keywords: Role of NGOs; Environmental Politics; Illegal Mining
\end{abstract}




\section{PENDAhuluan}

Ketimpangan pengelolaan sumber daya alam terutama di daerah telah menjadi isu krusial yang sering diabaikan. Sejumlah penelitian yang dilakukan tentang keadaan alam Indonesia setiap tahun mengalami kerusakan dan deforestasi lahan yang terus menerus yang berdampak pada kehidupan masyarakat baik sosial, ekonomi dan lingkungan hidu. ${ }^{1}$ Pasca reformasi pengelolaan sumber daya alamdiatur dalam Pasal 33 UndangUndang Dasar Tahun $1945^{2}$, bahwa pengelolaan sumber daya alamyang seharusnya memberi manfaat bagi masyarakat secara adil dan berbagai pihak secara luas adalah untuk sebesar-besarnya kemakmuran rakyat, secara berkeadilan dan berkelanjutan.Pada pelaksanaannya masih belum sesuai dengan amanat UUD 1945.

Seiring terjadinya kerusakan lingkungan yang umumnya disebabkan oleh aktivitas pertambangan baik legal maupun illegal. Data Dinas Energi dan Sumber Daya Mineral Provinsi Sumatera Barat bahwa untuk tahun 2015 ada 327 izin yang tersebar dan untuk tahun 2016 ada 252 izin usaha pertambangan hadir ${ }^{3}$.Ada 60 perusahaan tambang tanpa izin yang tersebar di Sumatera barat dengan jumlah pelaku 6.999 Orang $^{4}$.

Dari data diatas degradasi sumber daya alam dan kerusakan lingkungan pasca tambang dan sejumlah bencana seperti banjir yang terjadi, serta pengawasan terhadap perizinan tambang ilegal yang marak terjadi di sejumlah daerah memicu gojolak dan perlawanan dari masyarakat. Sebagai masalah politik lingkungan dilihat dari kontestasi peran, pengaruh, kepentingan dan relasi kuasa diantara para aktor yang menentukan tata kelola lahan. Salah satu aktor penting dalam isu politik Lembaga Swadaya Masyarakat (LSSM). ${ }^{5}$ Peran LSM lingkungan diwujudkan dalam diplomasi lingkungan hidup pada tingkat global, nasional, maupun daerah. Menggugah kesadaran publik, menggugat kebijakan negara, serta menggalang protes dan boikot terhadap perusahaan perusak

\footnotetext{
${ }^{1}$ Iwan Nugroho dan Rokhman Dahuri, Pembangunan Wilayah Perspektif Ekonomi, Sosial dan Lingkungan, 232

${ }^{2}$ Dalam UUD 1945 Pasal 33 :(1)Perekonomian disusun sebagai usaha bersama berdasar atas asas kekeluargaan.(2) Cabang-cabang produksi yang penting bagi negara dan yang menguasai hajat hidup orang banyak dikuasai oleh negara.(3) Bumi dan air dan kekayaan alam yang terkandung di dalamnya dikuasai oleh negara dan dipergunakan untuk sebesar-besar kemakmuran rakyat.(4) Perekonomian nasional diselenggarakan berdasar atas demokrasi ekonomi dengan prinsip kebersamaan, efisiensi berkeadilan, berkelanjutan, berwawasan lingkungan, kemandirian, serta dengan menjaga keseimbangan kemajuan dan kesatuan ekonomi nasional.(5) Ketentuan lebih lanjut mengenai pelaksanaan pasal ini diatur dalam undangundang.

${ }^{3}$ Laporan Gerakan Nasional Penyelamatan Sumber Daya Alam Provinsi Sumatera Barat tahun 2017. diakses di https://antikorupsi.org/sites.pdf diakses pada Kamis 11 April 2019 pkl 05.00

${ }^{4}$ Ibid

${ }^{5}$ Ahmad M. 2006. Gerakan Ornop Lingkungan di Indonesia. J Jentera Hukum. 13(3):10-15.
} 
lingkungan hidup serta mempengaruhi perilaku perusahaan untuk mematuhi standar keberlanjutan lingkungan hidup.

Salah satu daerah di Sumatera Barat yang memiliki sejumlah masalah polemik mengenai tambang yaitu, Kota Padang merupakan salah satu daerah banyak terjadi aktivitas tambang khususnya tambang ${ }^{6}$. Kota Padang dengan luas 694,93kmyang merupakan ibukota dari Provinsi Sumatera Barat (BPS, 2016) terletak di pantai barat Pulau Sumatera dan terbentuk dari perpaduan antara dataran rendah, perbukitan, dan pegunungan. ${ }^{7}$ Berdasarkan data yang diperoleh dari Dinas Perindustrian, Perdagangan, Pertambangan dan Energi Kota Padang mengenai Izin Usaha Pertambangan (IUP) Kota Padang Tahun 2015 terdapat hanya 22 IUP yang terdaftar dan tersebar di kota Padang, dimana sampai pada tahun 2016 ini hanya terdapat 10 IUP yang masih aktif dan selebihnya masa berlakunya telah habis ${ }^{8}$.

Tabel 1.1 Sebaran Daerah Tambang di Kota Padang

\begin{tabular}{lll}
\hline Kecamatan & Kelurahan & $\begin{array}{l}\text { LokasiTamban } \\
\text { g }\end{array}$ \\
\hline Kuranji & Kelurahan Gunung Sarik & Gunuang Sarik \\
Pauh & Kelurahan Limau Manis Selatan & Batu Busuak, \\
& Kelurahan Lambung Bukit & Bukik Bulek \\
& & Kampung \\
Koto Tangah & Kelurahan Balai Gadang Kelurahan Koto Panjang Balai Gadang \\
& Ikua & Koto Panjang \\
& Lubuk Minturun Aia Dingin & Lubuk Minturun \\
& Kelurahan Batipuah Panjang & Aia Dingin \\
& & Batang Kandis, \\
& & Anak Aia \\
Lubuk Kilangan & Kelurahan Batu Gadang & Batu Gadang \\
\hline
\end{tabular}

\footnotetext{
${ }^{6}$ Peraturan Pemerintah No. 27 Tahun 1980 tentang jenis bahan galian, yaitu:Bahan galian golongan A atau bahan galian golongan strategis. Yang dimaksud strategis adalah strategis bagi pertahanan/keamanan negara atau bagi perekonomian Negara seperti, minyak bumi, bitumen cair, lilin bumi, gas alam dan timah.Bahan galian golongan B atau bahan galian vital, adalah bahan galian yang dapat menjamin hajat hidup orang banyak, seperti , besi, mangan, titanium, tembaga, timbal, seng, emas, platina, perak, air raksa, intanBahan galian golongan $\mathrm{C}$ atau bahan galian industri, seperti garam batu, Pasir kwarsa, kaolin, gips, batu apung, marmer, batu tulis, batu kapor, tanah liat, dan pasir.

${ }^{7}$ Dinas ESDM Provinsi Sumatera Baratdiakses di esdm.sumbarprov.go.ig pkl 04.40 Pada Jumat 29 Maret 2019

${ }^{8}$ Dinas ESDM Provinsi Sumatera Barat diakses di esdm.sumbarprov.go.ig
} 
Indarung

\section{Sumber ; Walhi Sumatera Barat}

Sampai saat ini pemerintah Kota Padang belum dapat mengelola sumber daya alam dengan baik, karena masih ditemukan beberapa titik di Kota Padang aktivitas tambang ilegal, salah satunya yang baru ditemukan di kawasan Lambung Bukit, Kecamatan Pauh, Kota Padang. Belakangan dihebohkan dengan aktifitas penambangan emas ilegal di kawasan Bukik Bulek, Sungkai. Aktifitas yang dilaporkan masyarakat belakangan ini terdapat kayu gelondongan, mesin dompeng, dan lubang bekas galian. Kemudian diinvestigasi oleh WALHI Sumatera Barat dan forum organisasi masyarakat setempat ditemukan sisa-sisa peralatan tambang, meski aktivitasnya sudah berhenti dan diketahui aktivitas tambang emas ilegal ini telah terjadi sejak tahun $2013^{9}$.

Dalam kasus tambang emas ilegal di Bukik Bulek adanya peranan WALHI Sumatera Barat sebagai LSM tunggal yang melakukan proses pendampingan dalam investigasi temuan alat alat bukti dalam kasus ini. Kasus tambang emas yang terjadi di Bukik Bulek di temukan pada tanggal 29 Januari 2018 WALHI bersama masyarakat serta tokoh masyarakat lainnya melakukan aksi investigasi atau pencidukan yang dilakukan bersama Forum Anak Nagari Kuranji Pauh IX (FKAN PAUH IX), pada kasus ini ditemukan adanya aktivitas tambang emas ilegal karena ditemukan sejumlah alat alat penambangan emas, akibat aktivitas ini adanya lubang lubang besar yang yang ada disekitar Bukit Bulek. Hal ini dapat dilihat dari kutipan salah satu tokoh masyarakat yaitu Deddy Azhari selaku anggota FKAN PAUH IX sebagai berikut ${ }^{10}$ :

...Ada peran WALHI waktu itu yang ikut melakukan pendampingan kepada kami serta masyarakat. Aksi massa dilakukan pada awal tahun 2018, di Bukik Bulek.

WALHI yang merupakan LSM tunggal yang melakukan pendampingan bagi masyarakat Kampung Sungkai, memainkan perannya sebagai Countervailing Power (Kekuatan Penyeimbang) dengan mendesak Pemeritah daerah untuk mengusut kasus izin pertambangan tambang emas illegal tersebut.

Dalam isu politik lingkungan yaitu pengelolaan sumber daya alam dengan fokus pada peran dan strategi LSM, sudah banyak ditelitik namun penulis berasumsi pada setiap

\footnotetext{
${ }^{9}$ Berita Temuan Tambang Emas Ilegal Diselidiki di Padang Diakseshttps://nasional.republika.co.id/s pada 23 Maert 2019 pkl 04.00

${ }^{10}$ Kutipan Wawancara dengan salah satu anggota FKAN PAUH IX Di kediaman beliau Kampung Sungkai pada selasa 21 Juni 2019
} 
daerah gerakan, peran dan strategi yang dilakukan di setiap daerah berbeda. Studi gerakan lingkungan hidup di Indonesia, lebih banyak menjelaskan mengenai tumbuh dan berkembangnya gerakan namun peneliti ingin membahas bagaimana peran WALHI Sumbar terhadap persoalan aktivitas tambang yang ada di Kota Padang.Dari kebaharuan penelitian yang peneliti tawarkan diatas maka dari itu pertanyaan penelitian peneliti adalah Bagaimana peran WALHI (Wahana Lingkungan Hidup) Sumatera Barat dalam persoalan tambang emas ilegal di Kota Padang.

\section{Studi Literatur}

Untuk memahami peran WALHI Sumatera Barat dalam kasus ini maka penulis memilih mengacu pada pendekatan Peran LSM oleh Arya Suryadi Culla, karena LSM merupakan gerakan lingkungan hidup salah satu bentuk gerakan sosial kontemporer yang termasuk dalam kategori gerakan sosial baru menurut peneliti demikian menganalisis peran dan strategi LSM dalam arena politik lingkungan hidup, Menggunakan 3 Peran LSM yaitu sebagai Countervailing Power (Kekuatan Penyeimbang), Empowerment (Pemberdayaan), dan Intermediary Instituion (Lembaga Perantara). Menggunakan konsep dan pendekatan diatas peneliti akan menjawab pertanyaan penelitian bagaimana dampak dari peran LSM terhadap kebijakan dan tata kelola dilihat bukan sebagai faktor tunggal, sehingga penulis lebih melihat bagaimana kontribusi dari peran dalam investigasi tambang emas ilegal di Kota Padang.

\section{Peran Countervailing Power}

Untuk memaparkan peran WALHI tersebut maka peneliti menggunakan konsep peran LSM oleh Adi Suryadi Culla ${ }^{11}$ bahwa LSM memainkan tiga peran yaitu peran sebagai Countervailing Power (Kekuatan Penyeimbang) yaitu LSM berperan sebagai kekuatan penyeimbang dalam mengendalikan, melawan dan menekan kekuasaan serta tipu daya yang dilakukan oleh elit politik dan korporasi kepada masyarakat. Peran ini bersifat politis, kritis, konfliktual dan transformatif. Peran ini biasanya dijalankan melalui advokasi kebijakan, lobi, pernyataan politik, petisi, aksi protes dan aksi unjuk rasa.

\footnotetext{
${ }^{11}$ Adi Suryadi Culla, Rekonstruksi Civil Society: Wacana dan Aksi Ornop di Indonesia, (Jakakarta: LP3ES, 2006), 301
} 


\section{Peran Empowerment}

Peran Empowerment (Pemberdayaan) adalah peran ini dijalankan melalui kegiatan mengembangkan kapasitas, produktivitas dan kemandirian kelompok-kelompok masyarakat, kemudian menumbuhkan kesadaran pada masyarakat dalam membangun keswadayaan, menjaga kemandirian, menggalang keikutsertaan berpartisipasi, dan memperkuat hak-hak warga negara. Peran ini biasanya dijalankan melalui pendidikan, pelatihan, pengorganisasian, pengerahan dan metode alternatif sesuai kepentingan masyarakat. Menurut konsep peran LSM oleh Adi Suryadi Culla, peran empowerment ini bersifat konstruktif dan reformatif ${ }^{12}$. Peran empowerment (pemberdayaan) merupakan upaya untuk meningkatkan kesadaran masyarakat, menyatu bersama masyarakat, dan mengembangkan kapasitas kelembagaan, produktifitas dan keswadayaan kelompok masyarakat dan masyarakat secara umum. Peran ini pada umumnya bertujuan untuk meningkatkan kesadaran akan hak-hak masyarakat, partisipasi masyarakat, serta kemandirian atau keswadayaan. Melalui cara mendekatkan diri dengan masyarakat, memberikan pendidikan maupun pelatihan, dan pengorganisasian masyarakat.

\section{Peran Intermediarry Institusion}

Peran Intermediary Institution menurut Adi Suryadi Culla merupakan peran yang memiliki sifat Partnership yaitu upayasebagai wadah atau jaringan kerja sama antar LSM dan organisasi forum masyarakat lainnya. Peran Intermediary Institution ini biasanya dapat dilakukan WALHI dengan mengadakan kerja sama antar kedua lembaga atau lebih, serta juga membentuk sebuah koalisi. Tujuan dari peran ini adalah untuk memudahkan pencapaian misi perihal isu dan kasus tertentu ${ }^{13}$. Adapun peran yang dilakukan LSM guna sebagai Intermediary Institution (Lembaga Perantara) yaituyang pertama kerja sama adalah sebuah usaha yang dilakukan oleh beberapa orang atau kelompok yang memiliki kepentingan dan kesadaran yang sama untuk bekerja sama mencapai tujuan tertentu. Kedua koalisi adalah sebuah atau sekelompok persekutuan gabungan atau aliansi beberapa unsur dimana dalam kerja samanya masing masing memiliki kepentingan sendiri sendiri. Dalam hal ini biasanya adanya koalisi antar LSM, dan biasanya bersifat sementara hingga kasus selesai dan berasas manfaat pembentukan koalisi, bahwa dalam suatu pergerakan lingkungan memerlukan membentuk aliansi kerja sama dalam bentuk koalisi guna mencapai tujuan tertentu.

\footnotetext{
${ }^{12}$ Adi Suryadi Culla, Rekonstruksi Civil Society: Wacana dan Aksi Ornop di Indonesia, (Jakarta: LP3ES, 2006), 37

${ }^{13}$ Rahmat Abdi, Peran LSM dalam Penguatan Civil Society di Indoesia, Hal 36
} 


\section{METODE PENELITIAN}

Dalam penelitian ini menggunakan metode kualitatatif dengan pendekatan studi kasus tipe deskriptif untuk mengetahui bagaimana peran WALHI SUMBAR dalam investigasi tambang emas illegal di Kota Padang. Metode kualitatif ini dipandang oleh Creswell yaitu melakukan framing atau sudut pandang perilaku manusia dan keyakinan dalam sosial-politik-historis dan serta kualitatif deskriptif sendiri juga termasuk dalam paradigma Post Positivis (Creswell, 2007). Penggunaan pendekatan dan tipe penelitian ini bertujuan agar peneliti bisa menjelaskan dan menggambarkan secara tertulis tentang fenomena yang peneliti angkat untuk disusun kedalam laporan penelitian yang kompleks dan efisien. Sehingga apa yang menjadi tujuan dari penelitian ini dapat terjawab dengan baik. Berdasarkan penjelasan tersebut, peneliti anggap lebih dapat untuk menjelaskan permasalahan penelitian secara komprehensif sesuai dengan kondisi alamiah masalah.

\section{HASIL dan PEMBAHASAN}

WALHI pro aktif terhadap sejumlah kasus lingkungan hidup terutama tambang di Kota Padang. Ini terlihat dari bagaimana WALHI Sumatera Barat melakukan pemetaan terhadap aktivitas galian tambang yang ada di Kota Padang.peneliti memilih studi kasus aktivitas tambang emas ilegal di Bukik Bulek, Kampung Sungkai Kelurahan Lambung Bukit Kecamatan Pauh. Untuk melihat bagaimana WALHI berperan sebagai aktor tidak langsung dalam tata kelola sumber daya alam,menurut Adi Suryadi Culla LSM memainkan tiga peran penting yaitu Countervailing Power (Kekuatan Penyeimbang), Intermediary Institution (Lembaga Perantara) dan Empowerment (Pemberdayaan). Dalam temuan lapangan penelitian ini peneliti menemukan bahwa WALHI hanya memainkan dua peran pada kasus tambang emas ilegal yang terjadi di Bukik Bulek Kampung Sungkai Kelurahan Lambung Bukit Kecamatan Pauh sebagai berikut:

\section{Tabel 1.2 Peran yang dilakukan oleh WALHI}

\begin{tabular}{|c|c|c|}
\hline $\begin{array}{c}\text { Peran sebagai Countervailing } \\
\text { Power (Kekuatan Penyeimbang) }\end{array}$ & $\begin{array}{c}\text { Peran sebagai Empowerment } \\
\text { (Pemberdayaa) }\end{array}$ & $\begin{array}{c}\text { Peran sebagai Intermediary } \\
\text { Institution (Lembaga Perantara) }\end{array}$ \\
\hline $\begin{array}{c}\text { 1. Lobby : } \\
\text { Menyurati Pemerintah (Dinas } \\
\text { ESDM) } \\
\text { 2.Pernyataan sikap / Siaran Pers } \\
\text { 3.Aksi Massa bersama } \\
\text { masyarakat Kel. Lambung Bukit } \\
\text { Kec. Pauh }\end{array}$ & $\begin{array}{c}\text { 1.Pengorganisasian Masyarakat } \\
\text { 2.Temu Kampung/Dialog antar } \\
\text { tokoh masyarakat } \\
\text { 3.Public Campign melalui } \\
\text { media Facebook, dan media } \\
\text { online Antara News Sumbar } \\
\text { serta melalui www.Walhi.org.id }\end{array}$ & $\begin{array}{c}\text { 1.Melakukan afiliasi dalam } \\
\text { bentuk kerja sama dengan : } \\
\text {-Forum Anak Nagari Kuranji } \\
\text { Pauh IX } \\
\text {-Persatuan Masayarakat Tani } \\
\text { Gunuang Nago }\end{array}$ \\
\hline
\end{tabular}

Sumber : Olahan Peneliti 
Pada kasus ini peneliti melihat peran WALHI Sumatera Barat mampu memunculkan pertisipasi masyarakat yang sebelumnya apatis terhadap aktivitas tambang emas ilegal tersebut, yang menurut beberapa informan pada saat penelititurun lapangan penelitian tambang emas illegal tersebut sudah ada sejak 2013, dan pada awal Januari 2018 dilakukan aksi massadan juga invetigasi besar besaran yang dilakukan oleh WALHI dan organisasi masyarakat, warga dan tokoh masyarakat lainnya, dari langkah yang dilakukan oleh WALHI beserta forum organisasi masyarakat setempat aktivitas tambang emas illegal ini berhenti sampai sekarang dan kelanjutannya telah diserahkan kepada pemerintah melalui aparat keamanan untuk mengusut pelaku tambang emas illegal tersebut 


\section{Bagan 1.1 Langkah Pengorganisasian Masyarakat}

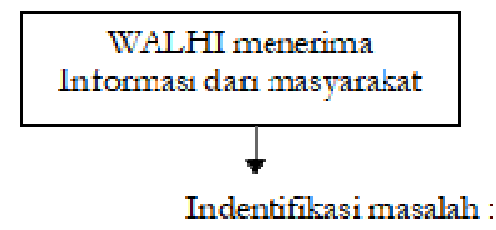

1.K Jarifilasi infomasi terkait ke pemerintah

2. indentifiknsi lokasi dan aktivitas Galian

3 . Identitikasi dampak linghingan

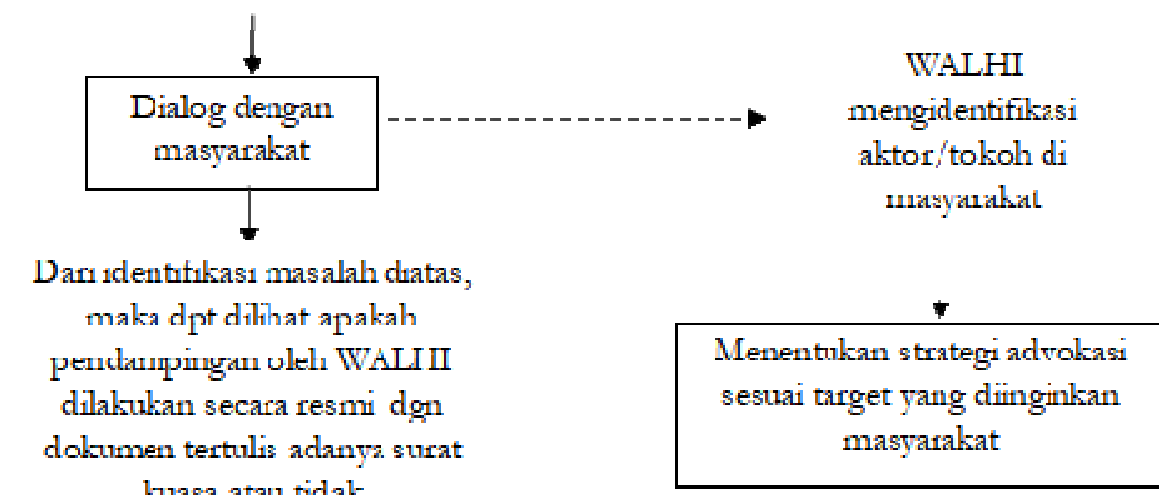

kuasa atau tidak

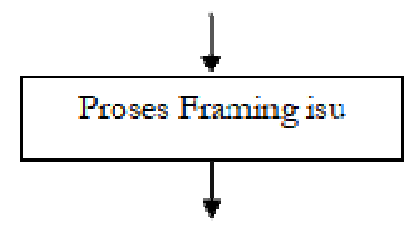

Bentuk strategi yang

digunakan

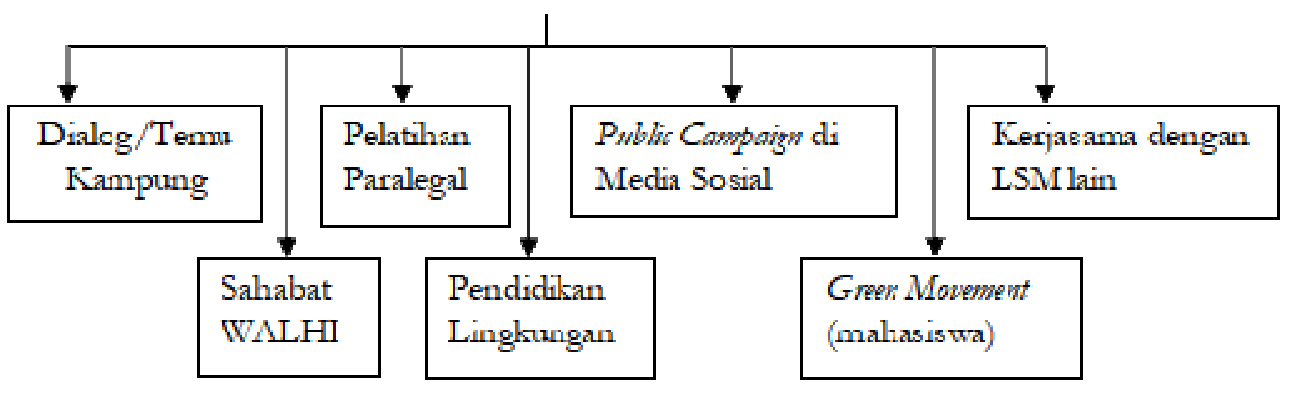

Sumber: Data Primer 
Berdasarkan bagan diatas terlihat peran empowerment dilakukan oleh WALHI Sumatera Barat dengan melakukan berbagai proses yang dilakukan. Jika dilihat dari bagan diatas WALHI memposisikan diri sebagai aktor yang menciptakan beberapa program untuk diaplikasikan kepada masyarakat atau implementasi program pelayanan, menurut Andra L Corrothers bahwa WALHI melakukan pemberdayaan masyarakat pada tingkat "grassroots" dilakukan dari yang sangat mendasar untuk mewujudkan pembangungan berkelanjutan.

WALHI melakukan peran empowerment dengan melakukan kegiatan Temu Kampung, WALHI melakukan kegiatan tersebut dua kali, yang pertama di bulan November yaitu membahas kronologi dan informasi terkait Galian di Bukik Bulek, pertemuan kedua dilakukan di Mesjid Kuba Kampung Pinang membahas mengenai strategi dan langkah advokasi apa yang akan dilakukan. Kegiatan Dialog bersama masyarakat diharapkan masyarakat mengetahui bahwa tambang emas illegal terjadi di wilayah dan lingkungan masyarakat, kegiatan itu adalah illegal dan tidak memiliki dokumen dan sifat hukum, WALHI Sumatera Barat menginginkan bahwa masyarakat melalui dialog dialog kecil serta diskusi santai dapat menyadarkan masyarakat bahwa persoalan lingkungan adalah persoalan bersama dan merupakan isu yang sangat penting di Indonesia bahwa aktivitas tambang illegal ini harus diawasi kalau tidak akan berdampak pada lingkungan sekitar masyarakat.

Pada tingkat lokal, LSM mampu memerankan diri sebagai organisasi gerakan sosial yang mendorong tumbuhnya aksi-aksi kolektif, jaringan lintas kelembagaan dan identitas kolektif sebagai sesama korban. LSM memanfaatkan kapasitas dan kompetensi mereka dalam mengisi ruang-ruang partisipasi dalam rangka mendorong perubahan tata kelola. Bentuk-bentuk peran antara lain adalah peran advokasi kebijakan, kampanye publik, penguatan kapasitas dan konsultasi, pengelolaan pengetahuan dan implementor di lapangan. Peneliti melihat bahwa keberhasilan suatu pergerakan lingkungan memerlukan membentuk aliansi kerja sama baik itu dalam bentuk kerja sama biasa atau koalisi dengan lembaga hingga forum masyarakat atau membangun kerja sama dalam bentuk jaringan LSM lain guna mencapai tujuan tertentu. Dalam kasus ini WALHI melakukan kerja sama dengan FKAN PAUH IX sehingga dapat memperngaruhi tokoh masyarakat lainnya.

\section{KESIMPULAN}

Fokus pada hasil penelitian, temukan dilapangan bahwasannya WALHI sebagai LSM merupakan aktor tidak langsungkarena WALHI merupakan aktor yang berada di luar pembuat kebijakan.Peran WALHI terhadap investigasi tambang emas ilegal di Bukik Bulek Kota Padang dilihat menggunakan konsep peran LSM yang diformulasikan Abdi Rahmat dan Adi Suryadi Culla bahwa suatu LSM memiliki peran-peran yang bisa dilakukan di antaranya sebagai Countervailing Power (Kekuatan Penyeimbang), dan Empowerment 
(Pemberdayaan) Dalam temuan lapangan peneliti WALHI hanya memainkan 2 peran dalam kasus investigasi tambang emas illegal di Bukik Bulek.

Peran yang dilakukan WALHI Sumatera Barat sebagai Countervailing Power (Kekuatan Penyeimbang) yakni lobby yang dilakukan dengan menyurati pemerintah melalui Dinas ESDM yang ditujukan ke pemerintah terkait kebijakan RTRW (Rencana Tata Ruang Wilayah) bahwa apakah aktivitas galian di Bukik Bulek memang dikeluarkan izin atau tidak, dan memang izin tambang emas tersebut tidak pernah dikeluarkan. Kemudian aksi bersama masyarakat dengan bentuk investigasi bersama terkait aktivitas yang dilakukan, namun sebelum terciduk pelaku sudah meninggalkan lokasi dan menyisakan alat alat berat untuk melakukan aktivitas tambang emas. Selain itu juga dengan mengeluarkan statement melalui media online maupun cetak, yang ditujukan kepada pemerintah untuk mengawasi aktivitas galian illegal yang ada di Kota Padang.

Pada peran Empowerment (Pemberdayaan) WALHI Sumatera Barat melakukan beberapa upaya kepada masyarakat dalam rangka meningkatkan kesadaran akan lingkungan di Kota Padang. Kesadaran atas hak-hak masyarakat yang dijamin undangundang, partisipasi masyarakat, serta meningkatkan kemadirian dan keswadayaan dalam bergerak. Pemberdayaan melalui cara pengorganisasian masyarakat, temu kampung atau dialog dengan tokoh masyarakat serta public campaign di media sosial. Adapun peran lain WALHI dalam temuan peneliti dalam proses framing isu,WALHI Sumbar membangun jaringan kerja dan menjalin kerja sama dengan forum masyarakat Pauh yaitu Forum Anak Nagari Kuranji (FKAN) PAUH IX, serta dengan Kelompok Tani Masyarakat Gunuang Nago.

\section{DAFTAR PUSTAKA}

Abdil Mughis, Mudhofir. (2011). Krisis Ekologi Dan Ancaman Bagi Kapitalisme Masyarakat. Jurnal Sosiologi. 16(1), 93-102.

Ahmad M. (2006). Gerakan Ornop Lingkungan di Indonesia. J Jentera Hukum

Barents,J. (1981). Pengantar Ilmu Politik. Jakarta: Erlangga.2000

Burhan Mungin. (2012). Metodologi Penelitian Kualitatif. Jakarta: PT. Raja Grafindo Persada

C.P.F Luhulima. (1998). "Politik Pembangunan Manusia dan Lingkungan" dalam Carunia Mulya Firdausy, ed,.Dimensi Manusia dalam Pembangunan Berkelanjutan. Jakarta: Lembaga Ilmu Pengetehauan Indonesia.

Gaffar Affan. (2006). Politik Indonesia: Transisi Menuju Demokrasi. Yogyakarta: Pustaka Pelajar 
Hidayat Herman, (2011). Politik Lingkungan: Pengelolaan Hutan Masa Orde Baru dan Reformasi. Jakarta: Yayasan Pustaka Obor Indonesia

John Clark. (1995). NGO dan Pembangunan Demokrasi. Yogyakarta: Tiara Wacana

K. Yin. Robert. (2012). Studi Kasus, Desain dan Metode. Jakarta: PT Raja Grafindo Persada

Lisa Jordan dan Peter Van Tuijl, ed., (2009). Akuntabilitas LSM: Politik, Prinsip dan Inovasi. Jakarta: LP3ES.

Mansour Fakih. (2010). Masyarakat Sipil untuk Transformasi Sosial: Pergolakan ideologi LSM di Indonesia, Yogyakarta: Insist Press

Mardalis. (2006). Metode penelitian suatu pendekatan proposal.. Jakarta: Bumi Aksara

Moleong.J. Lexy. (2007). Metode Penelitian Kualitatif. Bandung: Remaja Rosda karya

Nugroho Iwan. Dan Rochman Dahuri. Pembangunan Wilayah Perspektif Ekonomi, Sosial dan Lingkungan. Hal 232

Prayogo Doddy. (2008). Konflik Antara Korporasi dengan Komunitas Lokal: Sebuah Kasus Empirik pada Industri Geotermal di Jawa Barat. Depok: FISIP UI Press.

Suryadi Culla, Adi. (2006). Rekonstruksi Civil Society: Wacana dan Aksi Ornop di Indonesia. Jakakarta: LP3ES

Artikel yang ditulis Walhi di situs web resmi Walhi berjudul "Wajah Hutan Indonesia" Diakses di http://www.walhi.or.id/en/campaign/forest-and-monoculture/56-jedatebang/95-wajah-hutanindonesia

Artikel yang ditulis Walhi di situs web resmi Walhi berjudul "Wajah Hutan Indonesia" Diakses di http:/www.walhi.or.id/en/campaign/forest-and-monoculture/56-jedatebang/95-wajah-hutanindonesia

Artikel, Eva Royandi dan Rucarsud Keiya. Kontestasi Aktor Dalam Pengelolaan Sumber Daya Alam Pesisir di Wilayah Pembangunan Teluk Reklamasi Jakarta. http://journal.uinsgd.ac.id/index.php/temali/article/download/3619/2411 Pada 20 April 2019 pkl 08.00

Effendi Arwan, Ernan Rustiadi, Masalah Pengelolaan Sumber Daya Alam dan Kebijakan Ekonomi Bagi Pengendalian Terhadap Kerusakannya. https://www.academia.edu/3450717/ pada tanggal 11 April 2019 pkl. 06.00

Ir.Medrizal Zam.MPE,PhD.Pengelolaan Sumber Daya Alam dan Lingkungan Hidup Berkelanjutan (Perspektif dari sisi Kebijakan). Diakses di 
https://multisite.itb.ac.id/ftsl/wp-Pengelolaan-SDALH-Berkelanjutan.pdf pada 13 April 2019 pkl 12.30

Jurnal Politik. Aktor dan Kepentingan politik.Diakses di Masyarakat Jurnal 1 Sosiologi Vol. 21, No. 2 , Juli 2016: 205-231pada 25 April 2019 pk1 21.00

Walhi Institute dan Eksekutive Nasional Walhi. Hasil Studi Kualitas Calon Legislatif DPRRI Pro Lingkungan Hidup 2014-2019

Waluya.Bagja, Pengelolaan dan Pemanfaatan Saumber Daya Alam. Diakses di http://file.upi.edu/Direktori/FPIPS/JUR/PEND/GEOGRAFI/BAGJAWALUYA/G EOGRAFI_DESAKOTA/Pengelolaan Sumber Daya Alam.pdf pada 13 April 2019 pkl 12.00

Antikorupsi.org 2017.Laporan GNSPDA (Gerakan Penyelamatan Sumber Daya Alam) di 4 Provinsi tahun 2018. (Diakses di https://antikorupsi.org/sites/default/files/Laporan/ diakses pada Kamis 11 April 2019 pkl 05.00

Kompas.com 2018. Jelang Tahun Politik Pemberian Izin Tambang Cenderung Tidak Terkontrol.diakses di https://nasional.kompas.com/ pada Sabtu 6 April 2019 pkl 17.00

Media Indonesia.com 2018. Izin Pertambangan di Sumbar Bermasalah. (diakses http://mediaindonesia.com/read/detail/96778-225-izin-pertambangan-di-sumbarbermasalah)

Republika.co.id 2018.Temuan Tambang Emas Ilegal di Kota Padang (diakses di https://nasional.republika.co.id/ pada 23 Maret 2019 pkl 04.00) 